\title{
Lessons about Causes and Management of an Ebola Outbreak
}

\author{
Aida Elargoubi ${ }^{1}$, Anis W. Belhaj Khelifa ${ }^{2}$, Ons Haddad' ${ }^{1}$, Salma Mhalla ${ }^{1}$, Nabil Sakly ${ }^{1}$, Maha \\ Mastouri $^{1}$
}

${ }^{1}$ Laboratory of Microbiology, University Hospital F. B Monastir, Tunisia

${ }^{2}$ Laboratory of Microbiology, University Hospital Mahdia, Tunisia

\section{Correspondence: \\ Aida Elargoubi, Department of Microbiology, University Hospital of Monastir, 1st June CHU Fattouma Bourguiba, 5000 Monastir, Tunisia \\ E-mail: aidaelargoubi@yahoo.fr Tel: $0021695012403 ; 95012403$}

Received: 03 June 2016

Accepted: 07 Dec 2016

Published Online: 05 April 2017

Published: 22 Dec 2017

Key words: EBOLA virus, disease, prevention, surveillance, vaccines, strategy

Citation: Elargoubi A, Belhaj Khelifa AW, Haddad O, Mhalla S, Sakly N, Mastouri M. Lessons about causes and management of an Ebola outbreak.

Folia Medica 2017;59(4):387-95 doi: 10.1515/folmed-2017-0032
Ebola virus disease (EVD) is one of the deadliest viral diseases. It is characterized by a high mortality rate due to the lack of effective and safe treatments or vaccines and its ability to spread at an unstoppable pace. The West Africa outbreak ended but the disease may strike again at any time. The latest epidemic was, by far, the deadliest to date. The most concern was why this outbreak was so different from the previous ones. We proposed in this review firstly to summarize the principal causes of its unprecedented spread and secondly to identify the steps for an effective management approach of a future Ebola outbreak. Attributes of the affected populations and insufficient control efforts were the main reasons of its amplification. This was complicated by a delayed international response. The health crisis was ignored for months until it got out of control. The management of Ebola presents a multitude of challenges in terms of preparedness and capacity to face an outbreak. In addition to the need for adequate health care facilities, ongoing surveillance tools, appropriate training of health workers and raising population awareness, readiness requires a large scale and coordinated international intervention to support affected and at-risk nations, to intensify their response activities and to strengthen their capacities. Constant interventions after the outbreak are still needed to ensure that vital health and related service institutions in these countries are fully prepared to respond to an eminent epidemic.

\section{INTRODUCTION}

Ebola virus disease (EVD) is one of the deadliest viral diseases currently known. It is characterized by a high mortality rate resulting primarily from the lack of efficacious and safe treatments or vaccines and the difficulty in containing the spread of the disease. ${ }^{1}$ The latest Ebola outbreak was unprecedented in scale with 11310 deaths out of a total of 28616 cases recorded as of May 2016. It garnered wide media attention throughout the world. Eight months after its beginning, it was considered as public health emergency of international concern by the World Health Organisation (WHO). ${ }^{1,2}$ The end of the outbreak was declared on January 14, 2016. However, WHO and local authorities have been keeping a consolidated surveillance system. The risk of additional small outbreaks due to the virus persisting in survivors after recovery remained high during the following months. On March 29, 2016, the end of the outbreak was declared for the second time. But, until April 2016, clusters of EBOLA cases continued to appear in Guinea and Liberia. $^{2,3}$

The fear of this disease is related not only to the risk of new resurgences and new outbreaks in the future but also to our unpreparedness. ${ }^{4-6}$ The management of Ebola outbreaks continues to be complicated by several challenges and shortcomings. These difficulties are related to limited information about Ebola virus transmission in humans and its evolution during serial passage over time. ${ }^{7}$ However, they are essentially related to clinical management of patients, contact tracing, disease surveillance, logistics, laboratory testing and attributes of the affected population. Many lessons were drawn and learnt from this epidemic and from assessment of the world's preparedness to handle it. ${ }^{9}$ In this review, we tried to summarize these lessons and to present the principal keys and requirements for an effective Ebola outbreak management approach. 


\section{WHY WAS IT THE MOST IMPORTANT AND LARG- EST OUTBREAK?}

The 2014 outbreak was the twenty-first Ebola outbreak. ${ }^{6}$ It was exceptionally important and the largest in history. ${ }^{1}$ Several factors contributed to the magnitude of this outbreak. The biological characteristics of the virus cannot explain the huge spread of the virus. The West Africa EBOLA virus strain represented a new clade with some patients having higher viral loads but this was not the main factor leading to the unprecedented spread of the disease. ${ }^{10}$ During the latest outbreak, levels of transmission appeared to be too high but this is not true. The basic reproduction number (BRN) (the average number of secondary infections generated by one case in an entirely susceptible population) ranged from 1.34 to 3.65 during the outbreaks in DRC (1995) and in Uganda (2000). However, if the necessary interventions had been made, the effective BRN would have decreased to 0.3-0.4. In epidemiology, if the BRN is lower than 1 , this means a patient with the disease cannot transmit the disease to another individual during the infection period. ${ }^{6}$

The spread of Ebola outbreaks was mainly attributed to a disequilibrium between the contagiousness of the disease and the preparedness and therefore the ability of health care facilities to slow the transmission of the virus. In addition to that, the attributes of the affected populations and their practices played an important role in the amplification of the outbreak. Finally the outbreak got out of control because the world community had taken too long to react. ${ }^{6,8,11}$

\section{INADEQUATE HEALTH CARE SYSTEM IN WEST AFRICA}

The critical determinant of the epidemic magnitude appears to be the speed at which rigorous control measures were implemented. In fact, during the West Africa outbreak, the medical system actually amplified the virus transmission, rather than contained it. More than 300 doctors and nurses died due to the lack of implementing appropriate conventional outbreak control and containment measures. ${ }^{12}$

Previous EVD outbreaks were contained thanks to early detection and isolation, contact tracing and monitoring, and compliance with rigorous protocols of infection prevention and control. ${ }^{1,13-15}$

The shortage of equipment, facilities, and skilled personnel in the endemic areas limited the supportive care that should have been provided to the general population in this emergency situation as it was delivered to infected health care personnel who were expatriated to resource-rich settings in Europe and North America. ${ }^{9}$

This view is reinforced by other facts. Structures for the management and treatment of EVD, and the laboratories for clinical and molecular analysis seem to have been more effective in Guinea where the outbreak was better controlled compared to other affected countries. ${ }^{1}$ Secondly, the seventh reported outbreak of EVD in the Democratic Republic of Congo was less extended because the response was faster and more effective in this country and its neighbours. ${ }^{16}$

\section{ATTRIBUTES OF THE AFFECTED POPULATION}

Social factors (poverty, urban density, population migration patterns...) contributed to an important transmission and more super-spreading events., ${ }^{9,17}$ Liberia, Sierra Leone and Guinea are among the 20 countries with the lowest index of human development, with more than $50 \%$ of the population living below the poverty line. ${ }^{11}$

Previous EVD outbreaks were limited in size and geographic distribution because most of them began and ended in rural areas unlike the 2014 Ebola epidemic which reached the urban areas in West Africa. The easy connection between Guinea, Liberia and Sierra Leone populations in rural towns, villages and densely populated national capitals facilitated the spread of the infection. ${ }^{13}$

Traditional practices such as bathing the bodies before burial and the contact with the body during the funeral facilitated the transmission of infection because Ebola virus can persist up to several hours after the death of an infected person. ${ }^{11,18}$ In fact, almost $60 \%$ of the Ebola cases had been linked to local funeral practices. Indeed, 3000 Ebola cases were conclusively linked to a single funeral according to the WHO. 6,19

Most of the community members lack adequate knowledge about the potential risk factors for Ebola transmission. This problem is further aggravated by the fact that most of the affected people are illiterate and have never been exposed to basic education services. ${ }^{19}$

The news of EVD, spread into Africa in 2014, created widespread media attention. Initially, the information was focused on the high infectivity and case fatality which created worry, fear and anxiety not only among the members of the community, but even among health care professionals, including doctors. ${ }^{6}$ 
The situation was exacerbated by the fact that most of those who came into contact with infected people did not seek the help of qualified medical professionals, but rather relied on traditional healers for the management of their complaints. Some reports even suggested that both health professionals and diagnosed patients left treatment centres. ${ }^{19}$

\section{DELAYED INTERNATIONAL RESPONSE}

International response to Ebola had been too slow and remained dangerously inadequate during the first eight months of the outbreak. ${ }^{11}$ A long lag period (from early December 2013 to March 2014) occurred in the West Africa outbreak between the retrospectively recognized initial cases, and subsequent outbreak declaration. This allowed community transmission to occur before any kind of control measures was implemented. ${ }^{1,20}$ The disease was considered as a public health emergency of international concern by the WHO eight months after its onset. ${ }^{1}$ The epidemic was controlled only when international, logistic and economic efforts were provided and a multidisciplinary international collaboration was performed. ${ }^{9}$

\section{HOW TO BE READY TO FACE EBOLA}

Preparedness and readiness for an EVD outbreak require appropriate health infrastructure, effective surveillance tools, trained medical personnel and educated population. ${ }^{9,21}$ In the next paragraphs, we explain the principal steps for an effective strategy to face Ebola in the future. However, it is difficult for the countries in at-risk zone to improve their health systems to a standard similar to that of high income countries without considerable donor support and international assistance to create the necessary infrastructure for patient care, prompt diagnosis, training, and the technology required for reporting an epidemic. ${ }^{22}$

\section{FACILITIES FOR PATIENT ISOLATION AND TRANSFER}

Ebola patients should be kept in single-patient rooms with bathrooms and closed doors. An anteroom for donning and doffing personal protection equipment (PPE) must be considered. If this is not possible, EVD confirmed patients should be isolated from those who still are under investigation for EVD. The Ministry of Health should consider having a number of designated facilities in different geographical areas to cope with any potential outbreak.
For countries that are not equipped with this kind of facilities, departments that have been devoted to the isolation of patients during influenza pandemic and/or those used for the isolation of patients with multidrug-resistant tuberculosis may be used. ${ }^{23}$

Patients must be handled by health care personnel who have received comprehensive training in performing preventive and control infection practices and procedures. ${ }^{24}$ It is essential to restrict the access of medical and non-medical personnel to isolation rooms and to assign only trained personnel. Moving patients with advanced disease and a poor prognosis to intensive care units must be discussed to reduce the risk of nosocomial infections. ${ }^{25}$ When the disease is detected in a health care institution that is not equipped with appropriate facilities, patients should be transferred to the designated hospital by trained health care professionals in an appropriate vehicle. The transfer team consists of 2 trained medics, a team leader and an Emergency Medical Services physician. The vehicle must transport only essential personnel for patient care. ${ }^{23,24}$ Driver compartment must be separated from the passenger compartment. It is recommend by CDC to create a positive-pressure environment in the driver compartment by turning on the ventilation in the driver compartment, an extra measure to guard against aerosol. The interior of the patient compartment and the stretcher must be enveloped with impervious barriers to prevent contamination of surfaces. A full complement of medical gear including a bag valve mask device, airway adjuncts, and equipment for intravenous access and volume resuscitation should be available in the patient compartment and be protected by impervious drapes. ${ }^{24}$

\section{LABORATORY FACILITIES}

Setting up a field-screening laboratory to handle samples safely, securely and timely is mandatory to facilitate prompt diagnosis and to guide the mode of patient care. ${ }^{9}$ Absence of laboratory confirmation means that infected persons might remain in the community, with a severe risk of unknowingly transmitting the virus to others. Moreover, in the absence of rapid laboratory support, persons with other common infectious diseases, such as malaria or dengue might be unjustifiably held in an Ebola 'transit' center as a precautionary measure and are thus at risk of contracting Ebola.

It is essential to realize that the maximum risk of acquisition of infection is not from EVD confirmed patients, but from the late detection or isolation of 
the suspect/probable cases. Laboratory diagnosis and isolation becomes really difficult as most of the symptoms present within the early stages of the disease are non-specific, and hence in most of the cases, many of the family members/health care workers have been already exposed, even before the EVD infection is detected. ${ }^{21}$

Detection is largely based on molecular testing techniques using the polymerase chain reaction (PCR). The exchange of information in real time, about the PCR results, is completely essential to improve the response capacity. The antigen detection can be also performed as a confirmatory test for immediate diagnosis. ${ }^{11}$ Yet, in many countries access to these diagnostic techniques, which can be expensive (especially when a panel of tests is required for differential diagnosis), still remains an insurmountable obstacle. ${ }^{26}$

\section{ADHERENCE TO GUIDELINES}

A strict adherence to guidelines for Ebola virus environmental infection control is of paramount importance. These guidelines were established by the CDC to highlight key considerations for general and direct patient care, PPE, disinfectant selection, cleaning, and waste disposal.

It's essential to ensure the correct use of PPE by health professionals at every stage of management of patients with EVD from the emergency medical care until patient isolation in infectious disease divisions. Direct care personnel must wear gloves, impermeable gowns, surgical masks, goggles (with anti-fog visor), and closed shoes. When not enough PPE is available, the following items can be reused following appropriate disinfection: goggles or eyewear must be washed with water and soap first and then disinfected with $70 \%$ alcohol. Impervious gowns or aprons that cannot be sent to the hospital laundry facilities must be disinfected with $0.05 \%$ sodium hypochlorite. ${ }^{23,27}$

For waste management, it is important to distinguish 2 types of wastes: care activity waste (points, syringes, tubing...) and human waste (urine, stool...). Ebola virus can remain viable on solid surfaces for up to fifty days and even longer when protected in body fluids such as vomit, blood, or stool. ${ }^{28}$

CDC assessed burial practices and cemetery management. During the epidemic, in high-incidence areas, all deceased persons should be buried by the burial teams within 24 hours. A strict monitoring will be required to ensure that people adhere to directives on safe funeral practices. Corpses must not be embalmed whatever the funerary practices of family or friends of the deceased are. They should be disinfected with hypochlorite solution $0.05 \%$, placed in resistant fluid body bag which must be properly closed and placed in a closed casket and inhumed by special teams at a depth of at least 2 meters. ${ }^{23}$ Cemeteries should be designated with marked graves and an isolated open area to limit pedestrian traffic. ${ }^{29}$

All sharp-edged objects must be disposed of in puncture resistant containers that should be discarded when $75 \%$ of their capacity is reached. All solid waste, with no sharp edges, must be disposed of in appropriate medical waste disposal plastic bags. ${ }^{23}$

Several disinfectants can be used. Chlorine, soap, and alcohol solutions or any product effective against non-enveloped viruses are able to destroy Ebola virus and to disinfect human wastes before throwing them into ditches. The Ebola virus can also be easily eliminated by heat and sodium hypochlorite (bleach) or calcium hypochlorite (bleaching powder) in appropriate concentrations. Therefore, it is recommended to proceed in three steps for infected materials: disinfecting with bleach $(1 / 100)$ for 30 minutes, drying and burning. ${ }^{30,31}$

For contaminated materials onsite or after transport to a medical waste incinerator, incineration, or disinfection by autoclave is the preferred method of disposal. ${ }^{32}$

Wiping and disinfecting floors, doors, and walls must be ensured from the facility entry to the isolation room and finally, a decontamination step and validation testing, using vaporized hydrogen peroxide or ultraviolet germicidal irradiation. ${ }^{27}$ Full PPE (gloves, waterproof gowns, surgical masks, goggles and closed shoes should be available for cleaning professionals. ${ }^{23}$

PPE doffing process should be correctly ensured to avoid professional contamination. Doffing process includes wiping the exterior of the impermeable suit and hood with disinfectant wipes before removal. After this, protective suit, eye and respiratory protection will be respectively removed. After every step, gloves are disinfected and removed at the end and hands are disinfected with alcohol based hand disinfectant. ${ }^{7}$

\section{CONTACT TRACING AND MONITORING SYSTEM}

Contact tracing appears actually to be the best way to stop the spread of EBOLA infection. ${ }^{1}$ It has been proved that if a single case is missed, a single contact becomes ill and is not isolated, a single lapse in infection control or the deceased is 
not buried safely, another chain of transmission can start. ${ }^{20}$ Thus, a clear need has been identified to strengthen the preparedness of all countries to rapidly detect and respond to an Ebola exposure. ${ }^{6}$ Border countries must increase surveillance for symptoms consistent with viral haemorrhagic fever, establish a close coordination with civil aviation and airport authorities and train health and community workers to detect, notify, and manage suspected cases. ${ }^{1,23,33}$

\section{TRAINING AND EDUCATION}

In addition to providing adequate medical supplies and facilities and taking timely protective measures, training and sensibilizing health care professionals are essential in the outbreak response plan. ${ }^{6}$ To be prepared to safely manage such patients, paramedics, and emergency medical technicians must be trained to implement standard and transmission-based precautions to prevent exposure to themselves and others.

Medical teams should be educated about the pathogen, its modes of transmission, prevention and treatment. A complete-based training focuses on proper donning, doffing of PPE in the presence of a trained observer because developing and maintaining a high level of competency with the use of PPE is vital for workforce safety. $5,24,33$

An adequate knowledge skill about hand hygiene and the relevant decontamination and disinfection procedures should be acquired by health workers and those who handle dead bodies at the time of post-mortem or burial activities. ${ }^{27}$

Furthermore, health workers who are engaged in tracing contacts in the community should avoid shaking hands, maintain a distance of more than one meter during an interview with the contacts, and always carry alcohol-based hand rub solutions. In fact, it is even recommended to constitute a committee in the affected areas and a person should be in charge of coordinating infection prevention and control activities in both hospitals and communities. It has been realized that careful implementation of the infection prevention and control measures can significantly reduce or stop the transmission of the disease in the community and among health care workers. ${ }^{31}$

A public communication should be released to increase people awareness of virus transmission and its prevention and to promote collaboration with health teams deployed in the area. Emerging technologies like mobile phones which have become ubiquitous in West Africa can enhance communication with populations and peripheral health centres. Open- source software programmes that receive and send bulk SMS messages can be used to educate people and to facilitate case reporting and surveillance. ${ }^{26}$

\section{CONSTANT INTERVENTIONS}

Management strategy of an infectious disease outbreak like EVD has implemented until now, mostly post outbreak interventions. However, the latest outbreaks in East, Central and West Africa highlighted the importance of an urgent assistance of health workers, international agencies, development partners and governments to perform not only the usual post outbreak interventions but constant interventions. ${ }^{9}$

Health practitioners in at-risk countries need to be kept constantly up to date with the latest epidemic response strategies reinforced by regular seminars and workshops. ${ }^{21,34}$

A holistic way is needed to deal with the threat of Ebola. Interventions need to focus on good understanding of the public views about Ebola. Incorporating community perspectives and beliefs helps health workers to gain the support of the population, to reduce fear, panic and antisocial sentiments during an Ebola outbreak and to achieve a comprehensive knowledge of EVD. It helps government officials and development partners to design effective approaches and perspectives for future public health threats. $^{21,34}$

Constant interventions should also be based on making significant improvements in health care infrastructure by improving isolation units, diagnostic laboratories and instituting infection control facilities and procedures. Post outbreak non-stop vigilance ensures that health care professionals and institutions in at-risk communities and countries are fully prepared to respond to an epidemic whenever and wherever it strikes. ${ }^{9}$

Research into the development of preventive vaccines and drugs has been spurred by the virus spread and the high fatality rate during the latest outbreak (Table 1). But experiments should continue to develop effective and safe vaccines to prevent the advent of Ebola outbreak in the future. Clinical trials of two selected protocols have been carried out in West Africa. These protocols are based on the combination of viral vectors to remarkably enhance the immune response in human and nonhuman primates: the cAd3 Ebola vaccine (recombinant chimpanzee adenovirus serotype 3 vectored Ebola vaccine) and the rVSV-ZEBOV (recombinant vesicular stomatitis virus Ebola Vaccine)..$^{25,35-37}$ 
Various drugs have been experimented for EVD but none of them have been fully tested for safety or effectiveness. However, the Food and Drug Administration has approved some experimental treatments for emergency use in patients with Ebola infection which are recapitulated in the next paragraphs. ${ }^{38,39}$

- Convalescent whole blood or plasma: transfusion of blood from convalescent patients might be beneficial in the acute phase of infection and may reduce mortality. ${ }^{39}$

- ZMapp: is a combination of three humanised monoclonal antibodies targeted at three EBOLA virus glycoprotein epitopes and is engineered for expression in tobacco plants. It has proven protective in non-human primates. It has not been tested on humans for safety and efficacy. Only seven doses were tested on infected patients during the latest outbreak and only one patient died. It was supplied and helped to rescue the first American Ebola infected patients in the latest outbreak. ${ }^{40}$

Other antiviral drugs have been developed like TKM - EBOLA (small interfering RNA anti RNA polymerase) which was tried on a small number of patients, or brincidovir (trial phase III for the treatment of CMV and adenovirus), favipiravir (RNA polymerase RNA dependent inhibitor active against influenza virus and is approved in Japan for influenza pandemics), BCX-4430 (adenosine analogue) and AVI-7537 (antisense phosphorodiamidatemorpholino oligomers). ${ }^{28,41}$

\section{CONCLUSION}

Many lessons should be learned from the latest Ebola outbreak particularly as regards its causes and management.

The causes of the rapid spread of the latest outbreak can be understood if one takes into account the socio-economic context in which the outbreak developed, the lack of knowledge on Ebola and cultural characteristics of the affected population.

In addition to this, it was, basically, a matter of anticipation. The epidemic could have been controlled if appropriate interventions such as early diagnosis, good laboratory service, case management,

Table 1. List of the most advanced Ebola virus vaccine trials ${ }^{24}$

\begin{tabular}{|c|c|c|c|c|c|c|}
\hline Vaccine & Status & Comapny & Feature & $\begin{array}{c}\text { Type of } \\
\text { protection }\end{array}$ & Dose & $\begin{array}{c}\text { Admini- } \\
\text { stration } \\
\text { route }\end{array}$ \\
\hline $\begin{array}{l}\text { A. Replicating } \\
\text { rVSV-ZAIV-GP }\end{array}$ & Phase 3 & $\begin{array}{l}\text { NewLink Genet- } \\
\text { ics and PHAC }\end{array}$ & Attenuated VSV & $\begin{array}{l}\text { Post exposure/ } \\
\text { Prophylactic }\end{array}$ & single & IM or ora \\
\hline $\begin{array}{l}\text { B. Non } \\
\text { replicating } \\
\text { cAd3-EBOV }\end{array}$ & Phase 3 & GSK and NIAID & $\begin{array}{l}\text { Attenuated } \\
\text { adenovirus }\end{array}$ & Prophylactic & single & IM \\
\hline $\begin{array}{l}\text { Vesiculo vax } \\
\text { Ebola }\end{array}$ & $\begin{array}{l}\text { Phase } 1 \\
\text { ongoing }\end{array}$ & $\begin{array}{l}\text { Profectus } \\
\text { Biosciences Inc }\end{array}$ & $\begin{array}{l}\text { Viral expression } \\
\text { vector (VSV) }\end{array}$ & $\begin{array}{l}\text { Post exposure/ } \\
\text { Prophylactic }\end{array}$ & & IM or ora \\
\hline Ebola rAd5 & $\begin{array}{l}\text { Preclinical } \\
\text { (Phase } 1 \\
\text { ongoing) }\end{array}$ & $\begin{array}{l}\text { Johnson \& } \\
\text { Johnson } \\
\text { (Crucell/ } \\
\text { Bavarian Nordic) }\end{array}$ & $\begin{array}{l}\text { Viral expression } \\
\text { vector (Adeno- } \\
\text { virus) }\end{array}$ & $\begin{array}{l}\text { Pre-exposure/ } \\
\text { Prophylactic }\end{array}$ & Multiple & I \\
\hline Ebola GP Ad5 & Phase 1 & $\begin{array}{l}\text { University of } \\
\text { Texas at Austin }\end{array}$ & $\begin{array}{l}\text { Viral expression } \\
\text { vector } \\
\text { (Adenovirus) }\end{array}$ & Prophylactic & I & IM \\
\hline EBOV GP & $\begin{array}{l}\text { Phase } 1 \\
\text { ongoing }\end{array}$ & Novavax Inc & nano particles & / & Multiple & $\mathrm{IM}$ \\
\hline EBOV Vaccinia & Phase 1 & Bavarian Nordic & $\begin{array}{l}\text { MVA, } \\
\text { Immunostimulant }\end{array}$ & 1 & l & $\mathrm{SC}$ \\
\hline
\end{tabular}

Abbreviations: VSV: vesicular stomatitis virus; MVA: modified vaccinia Ankara; Ad: adenovirus; GP: Glycoprotein; r: recombinant; IM: intramuscular; SC: subcutaneous; /: non indicated 
patient isolation, contact tracing, infection control, safe burial and community involvement had been implemented.

For several years, EVD has been considered a strictly African disease. But the latest outbreak has shown that this attitude has to be changed and Ebola must be considered a public health problem of international concern. A large scale and coordinated international response is still needed to support affected and at-risk nations, to intensify their response effectiveness and to strengthen their capacities.

Ongoing implementation of preventive measures based on education, training, efficient facilities and vaccines development could be the keys to effectively facing EVD in the future. New systems and technologies to improve the detection of biological agents and methodologies to manage the spread of agents are still required for an effective EBOLA outbreak management strategy.

\section{CONFLICT OF INTEREST}

We declare that we have no conflict of interest.

\section{REFERENCES}

1. Cenciarelli O, Pietropaoli S, Malizia A, et al. Ebola virus disease 2013-2014 outbreak in West Africa: An analysis of the epidemic spread and response. Int J Microbiol 2015;2015:1-12.

2. Organisation mondiale de la santé (OMS). EBOLA data and statistics. http://apps.who.int/iris/bitstream/10665/208876/1/ebolasitrep_2June2016_fre. pdf ? ua=1 (accessed on 28 September 2016)

3. Center for Disease Control and prevention (CDC). Ebola (Ebola virus disease). 2014 Ebola outbreak in West Africa - Case Counts. Available from: http:// www.cdc.gov/vhf/ebola/outbreaks/2014-westafrica/case-counts.html (accessed on 28 September 2016)

4. Organisation mondiale de la santé (OMS). Rapport de la situation sur la flambée de maladie à virus EBOLA 30 mars 2016. Available from: http://apps. who.int/iris/bitstream/10665/205012/1/ebolasitrep_30 Mar 2016_fre.pdf? ua (accessed on September 28, 2016).

5. Wiwanitkit V. Preparedness for the management of a patient with Ebola. Eur J Intern Med 2015;26:453.

6. Ki M. What do we really fear? The epidemiological characteristics of Ebola and our preparedness. Epidemiol Health 2014;36:1-4.

7. Gałas A. The determinants of spread of Ebola virus disease - An evidence from the past outbreak experiences. Folia Med Cracov 2014;3:17-25.

8. Osterholm MT, Moore KA, Kelley NS, et al. Trans- mission of Ebola viruses: What we know and what we do not know. MBio 2015;6:1-8

9. Matua GA, Van der Wal DM, Locsin RC. Ebola hemorrhagic fever outbreaks: strategies for effective epidemic management, containment and control. Braz J Infect Dis 2015;19:308-13

10. Baize S, Pannetier D, Oestereich L, et al. Emergence of Zaire Ebola virus disease in Guinea. N Engl J Med 2014;371:1418-25.

11. Troncoso A. Ebola outbreak in West Africa: a neglected tropical disease. Asian Pac J Trop Biomed 2015;5(4):255-9.

12. Tambo E. Non-conventional humanitarian interventions on Ebola outbreak crisis in West Africa: health, ethics and legal implications. Infect Dis Poverty 2014;3(1):1-11.

13. WHO Ebola response team. Ebola virus disease in West Africa - The first 9 months of the epidemic and forward projections. N Engl J Med 2014;371:1481-95.

14. Shears P, O'Dempsey TJD. Ebola virus disease in Africa: epidemiology and nosocomial transmission. J Hosp Infect 2015;90:1-9.

15. Kmietowicz Z. WHO will review its response to Ebola once outbreak is under control. BMJ 2014;349:g6390.

16. Maganga GD, Kapetshi J, Berthet N, et al. Ebola virus disease in the Democratic Republic of Congo. N Engl J Med 2014;371:2083-91.

17. Gatherer D. The Ebola virus disease outbreak in West Africa. J Gen Virol 2104;95:1619-24.

18. Iliyasu G, Ogoina D, Otu AA, et al. A multi-site knowledge attitude and practice survey of Ebola virus disease in Nigeria. Plose One 2015;10:1-13.

19. Shrivastava SR, Shrivastava PS, Ramasamy J. Ebola disease: an international public health emergency. Asian Pac J Trop Dis 2015;5(4):253-62.

20. Galas A. The evolution of EBOLA virus disease outbreaks. Folia Med Cracov 2014;3:27-32.

21. Roca A, Afolabi MO, Saidu Y, et al. Ebola: A holistic approach is required to achieve effective management and control. J Allergy Clin Immunol 2015;135:856-67.

22. Ross GP, Crow SM, Tyndall MW. Planning for the next global pandemic. Int J Infect Dis 2015;38:89-94.

23. World Health organization, Pan American Health Organization. Ebola virus disease (EVD) implications of introduction in the Americas. Corrigendum 13-August 2014. Available from http://www.paho. org/hq/index.php?option $=$ com_docman\&task $=$ doc view\&gid $=26413+\&$ Itemid $=999999 \&$ lang $=$ en $(\mathrm{ac}-$ cessed on 28 April 2016).

24. Isakov A, Miles W, Gibbs S. Transport and management of patients with confirmed or suspected Ebola virus disease. Ann Emerg Med 2015;66:297-305. 
25. Ohimain EI. Recent advances in the development of vaccines for Ebola virus disease. Virus Research 2016;211:174-85.

26. Ansumana R, Bonwitt J, Stenger DA, et al. Ebola in Sierra Leone: a call for action. Lancet 2014;384:303-3.

27. Lowe JJ, Olinger PL, Gibbs SG, et al. Environmental infection control considerations for Ebola. Am J Infect Control 2015;43:747-9.

28. Judson S, Prescott J, Munster V. Understanding Ebola virus transmission. Viruses 2015;7:511-21.

29. Nielsen CF, Kidd S, Sillah AR, et al. Centers for Disease Control and Prevention. Improving burial practices and cemetery management during an Ebola virus disease epidemic - Sierra Leone, 2014. Available from: https://www.cdc.gov/mmwr/preview/mmwrhtml/mm6401a6.htm (accessed on 12 November, 2016).

30. Olszanecki R, Gawlik G. Pharmacotherapy of Ebola hemorrhagic fever: a brief review of current status and future perspectives. Folia Med Cracov 2014;3:67-77.

31. Shrivastava SR, Shrivastava PS, Ramasamy J. Ebola disease: an international public health emergency. Asian Pac J Trop Dis 2015;5:253-62.

32. Fisher WA, UyeKi TM, Tauxe RV. Ebola virus disease: What clinicians in the US need to know? Am J Infect Control 2015;43:788-93.

33. Budzyn DM. Ebola virus disease control in Po- land - are we ready for fight? Folia Med Cracov 2014;3:33-7.

34. Abdulaziz M, Taiwo LS, Saheed G, et al. An evaluation of psychological distress and social support of survivors and contacts of Ebola virus disease infection and their relatives in Lagos, Nigeria: a cross sectional study - 2014. BMC Public Health 2015;15:1-8.

35. Choi WY, Hong KJ, Hong JE, et al. Progress of vaccine and drug development for Ebola preparedness. Clin Exp Vaccine Res 2015;4:11-6.

36. Ye L, Yang C. Development of vaccine for prevention of Ebola virus infection. Microbes Infect 2015;17:98-108.

37. Marcinkiewicz J, Bryniarski K, Nazinek K. Ebola haemorrhagic fever virus: pathogenesis, immune responses, potential prevention. Folia Med Cracov 2014:3:39-48.

38. Bociaga-Jasik M, Piatek A, Garlicki A. Ebola virus disease - Pathogenesis, clinical presentation and management. Folia Med Cracov 2014;3:49-55.

39. Kilgore PE, Grabenstein JD, Salim AM, et al. Treatment of Ebola virus disease. Pharmacotherapy 2015;35:43-53.

40. Choi WY, Hong KJ, Hong JE, et al. Progress of vaccine and drug development for Ebola preparedness. Clin Exp Vaccine Res 2015;4:11-6

41. De Clercq E. Ebola virus (EBOV) infection: therapeutic strategies. Biochem Pharmacol 2015;93:1-10. 


\title{
Причины и противодействие эпидемии лихорадки Эбола
}

\author{
Аида Еларгуби ${ }^{1}$, Анис У. Бел Хадж Кхелифа ${ }^{2}$ Онс Хадад ${ }^{1}$, Салма Мхала ${ }^{1}$, Набил Сакли ${ }^{1}$, \\ Маха Мастури ${ }^{1}$ \\ 1 Лаборатория микробиологии, Университетская больница Ф. Б., Монастир, Тунис \\ 2 Лаборатория микробиологии, Университетская больница, Махдиа, Тунис
}

\begin{abstract}
Адрес для корреспонденции: Аида Еларгуби, Университетская больница Ф. Б. Монастир, Микробиология, "Первое июня" Университетская больница Фатума Бургиба , 5000, Монастир, Тунис

E-mail:aidaelargoubi@yahoo.fr Тел:0021695012403;95012403
\end{abstract}

Дата получения: 03 июня 2016 Дата приемки: 07 декабря 2016 Дата онлайн публикации: 05 апреля 2017

Дата публикации: 22 декабря 2017

Ключевые слова: эболавирус, превенция, наблюдение, вакцины, стратегия

\section{Образец цитирования:}

Elargoubi A, Belhaj Khelifa AW, Haddad O, Mhalla S, Sakly N, Mastouri M. Lessons about causes and management of an Ebola outbreak.

Folia Medica 2017;59(4):387-95. doi: 10.1515/folmed-2017-0032
Лихорадка Эбола является одной из самых смертоносных вирусных болезней в мире. Она характеризуется высокой смертностью в силу отсутствия эффективного и безопасного лечения или вакцин и благодаря её способности неудержимого распространения. Эпидемия в южной части Африки находится под контролем, но болезнь может вспыхнуть в любое время. Последняя по времени эпидемия оказалась самой смертоносной на тот момент. Первостепенной нашей задачей стало установление причин отличия последней эпидемии от предшествующих. Мы предлагаем вашему вниманию настоящий обзор по двум причинам. Во-первых, чтобы обобщить основные причины беспрецедентного распространения и во-вторых - с целью определить пошаговый подход для эффективного противодействия эпидемии лихорадки Эбола в будущем. Среди причин распространения болезни, основными являются характеристики пострадавшего населения и недостаточные усилия в отношении контроля заболевания. Запоздалая международная реакция дополнительно усугубила ситуацию. Кризисную ситуацию игнорировали в течение месяцев, пока она не вышла из-под контроля. Борьба с лихорадкой Эбола требует решения множества проблем в области подготовки и наличных средств противодействия эпидемии. Среди них следует обратить внимание на наличие подходящих лечебных заведений, постоянных средств наблюдения, на соответствующее обучение медицинских работников и на повышение информированности населения. Подготовка требует широкообхватного и согласованного международного содействия в поддержку пострадавших и рискованных стран. Необходимы постоянные действия после вспышки эпидемии, чтобы убедиться, что здравоохранительные и связанные с ними учреждения в этих странах находятся в полной готовности противодействовать неизбежной эпидемии. 